\title{
Identifikasi Kemampuan Koneksi Matematis Siswa Ditinjau dari Kemampuan Spasial pada Topik Prisma dan Limas
}

\section{Sofyan Nuna ${ }^{*}$, Resmawan ${ }^{2}$, Dewi Rahmawaty Isa ${ }^{3}$}

\author{
1,2,3 Jurusan Matematika, Fakultas MIPA, Universitas Negeri Gorontalo,
}

Jl. Prof. Dr. Ing. B. J. Habibie, Tilongkabila, Kabupaten Bone Bolango, Gorontalo 96119, Indonesia

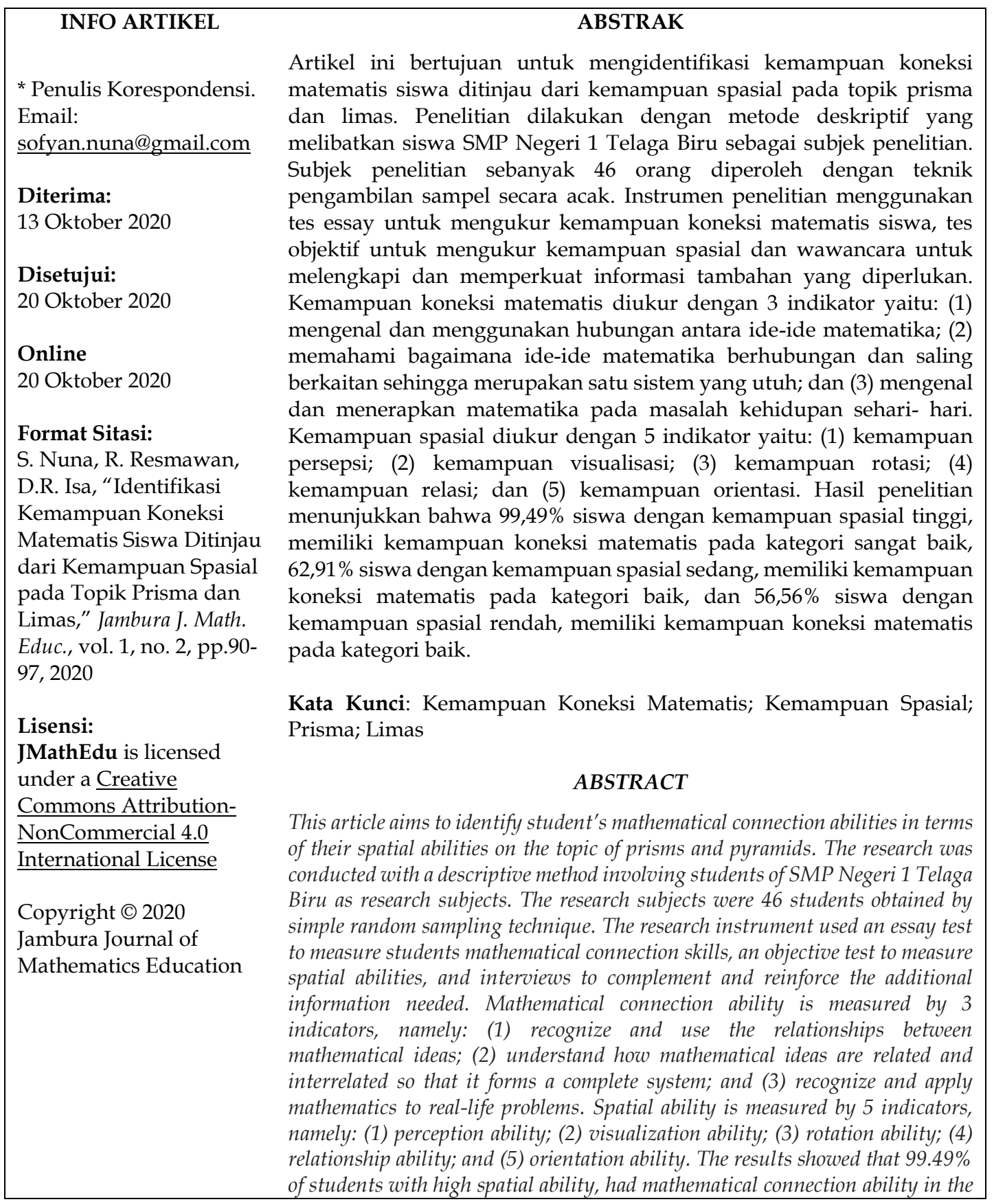


S. Nuna, dkk | Identifikasi Kemampuan Koneksi Matematis Siswa Ditinjau dari Kemampuan ...

very good category, $62.91 \%$ of students with medium spatial ability, had mathematical connection ability in the good category, and $56.56 \%$ of students with low spatial ability, had mathematical connection ability in the good category.

Keywords: Mathematical Connection Ability; Spatial Ability; Prism; pyramid

\section{Pendahuluan}

Kurikulum nasional menuntut siswa dari tingkat sekolah dasar sampai perguruan tinggi untuk menguasai materi geometri bidang dan geometri ruang yang notabene juga membutuhkan kemampuan spasial. Demikian pentingnya kemampuan spasial ini sehingga kita semua terutama para guru dituntut untuk memberikan perhatian yang lebih agar kemampuan spasial diajarkan dengan sungguh-sungguh sesuai dengan amanat kurikulum. Guru dapat menggunakan pendekatan pembelajaran yang cocok dan secara teoritis dapat meningkatkan hasil belajar siswa. Namun disisi lain, siswa juga dituntut untuk memiliki kemampuan dasar yang dapat dikembangkan untuk memperoleh hasil yang maksimal.

Tinggi rendahnya kemampuan koneksi siswa dalam mengkaitkan konsep-konsep matematika menjadi salah satu indikator pengajaran matematika di sekolah, khususnya sekolah menengah pertama. Pembelajaran matematika disekolah diharapkan tidak hanya sebatas membuat catatan, tetapi siswa mampu menangkap arti dan makna dari pembelajaran yang diberikan oleh guru. Keterkaitan antar konsep atau prinsip dalam matematika memegang peranan yang sangat penting dalam mempelajari matematika. Dengan kemampuan tersebut maka siswa memahami matematika secara lebih menyeluruh dan lebih mendalam.

Hingga kini, guru mata pelajaran masih sering dipertemukan dengan persoalan dimana siswa kesulitan untuk mengaitkan topik yang satu dengan topik yang lain walaupun diketahui topik-topik tersebut saling berhubungan satu sama lain. Hal ini terutama sering ditemukan pada pembelajaran bangun ruang yang berkaitan dengan objek atau gambar geometri seperti limas dan prisma. Seperti yang kita ketahui bahwa geometri merupakan salah satu topik matematika yang penting diajarkan di sekolah. Tujuan geometri diajarkan di sekolah adalah agar anak dapat menggunakan visualisasi, mempunyai kemampuan spasial dan pemodelan geometri.

Berbagai upaya untuk mencari solusi dari problematika pembelajaran matematika, baik dari kemampuan koneksi matematis siswa, kemampuan spasial, maupun yang mengarah pada topik khusus geometri seperti prisma dan limas masih terus dilakukan. Penelitian terkait kemampuan koneksi matematis siswa misalnya, sejauh ini banyak dikaji dalam kaitannya dengan kondisi siswa dalam mengikuti pelajaran ataupun capaian pembelajaran siswa seperti yang dapat ditemukan pada [1][2][3]. Demikian juga dengan upaya untuk melakukan analisis terhadap kemampuan koneksi matematis siswa atau menggunakannya untuk mencari solusi dari suatu permasalahan seperti yang terdapat pada [4][5][6]. Sama halnya dengan kemampuan koneksi matematis, kemampuan spasial juga telah banyak dibahas sebelumnya dalam berbagai persepsi. Upaya meningkatkan kemampuan spasial siswa dapat ditemukan pada [7][8], termasuk pembahasan khusus terkait profil kemampuan spasial yang terdapat pada [9][10]. Disamping itu, upaya-upaya untuk mengaitkan kemampuan spasial dengan matematika juga terus dikaji sebagaimana yang dapat ditemukan pada [11][12]. Adapun 
penelitian terkait geometri baik yang secara umum maupun yang terkait dengan geometri dimensi tiga dapat ditemukan pada [13][14][15][16]. Termasuk hal yang menarik bahwa dari begitu banyak penelitian yang telah disebutkan sebelumnya, belum ada pembahasan khusus yang mengaitkan antara kemampuan koneksi matematis dengan kemampuan spasial yang dimiliki oleh siswa, utamanya dalam pembahasan terkait geometri pada topik prisma dan limas.

Oleh karena itu, dalam artikel ini kami melakukan identifikasi terhadap kemampuan koneksi matematis siswa ditinjau dari kemampuan spasial yang dimiliki, dalam kaitannya dengan topik prisma dan limas.

\section{Metode}

Metode yang digunakan dalam penelitian ini adalah metode penelitian deskriptif untuk mengidentifikasi kemampuan koneksi matematis siswa ditinjau dari kemampuan spasial pada topik prisma dan limas. Penelitian melibatkan siswa SMP Negeri 1 Telaga Biru sebagai subjek penelitian. Subjek penelitian yang dilibatkan berjumlah 46 siswa yang diperoleh dengan teknik simple random sampling. Semua sampel diberikan tes kemampuan spasial untuk mengelompokannya ke dalam kemampuan spasial tinggi sedang, dan rendah dengan mengacu pada Tabel 1.

Tabel 1. Kategori kamampuan spasial berdasarkan nilai rata-rata dan standar deviasi

\begin{tabular}{ccc}
\hline No & Perolehan Nilai $(\mathrm{N})$ & Kategori Kemampuan Spasial \\
\hline 1 & $N \geq \bar{x}+S D$ & Tinggi \\
2 & $\bar{x}-S D<N<\bar{x}+S D$ & Sedang \\
3 & $N \leq \bar{x}-S D$ & Rendah \\
\hline
\end{tabular}

Data yang digunakan berupa data kemampuan spasial siswa yang diperoleh melalui tes objektif dan data kemampuan koneksi matematis siswa yang diperoleh melalui tes essay. Pengumpulan data dilakukan dengan memberikan instrumen tes yang terdiri dari seperangkat pertanyaan/soal berbentuk soal objektif dan essay pada materi limas dan prisma. Semua intrumen yang digunakan dilakukan uji validitas konstruk dan isi sehingga data yang diperoleh dari instrument dapat dipertanggungjawabkan.

Dalam penelitian ini data yang disajikan berupa identifikasi kemampuan koneksi matematis menggunakan analisis presentase. Untuk mengetahui presentase kemampuan koneksi matematis digunakan rumus sebagai berikut:

$$
\text { Kemampuan Siswa }=\frac{\sum \text { skor yang diperoleh }}{\sum \text { skor maksimum }} \times 100 \%
$$

\section{Hasil dan Pembahasan}

\subsection{Deskrisi Data Hasil Penelitian}

Data yang dideskripsikan dalam penelitian ini terdiri dari:

a. Kemampuan koneksi matematis siswa untuk peserta didik yang memiliki kemampuan spasial tinggi, 
S. Nuna, dkk | Identifikasi Kemampuan Koneksi Matematis Siswa Ditinjau dari Kemampuan ...

b. Kemampuan koneksi matematis siswa untuk peserta didik yang memiliki kemampuan spasial sedang, dan

c. Kemampuan koneksi matematis siswa untuk peserta didik yang memiliki kemampuan spasial rendah.

Pengelompokkan sampel kedalam kemampuan spasial tinggi, kemampuan spasial sedang dan kemampuan spasial rendah dilakukan dengan menentukan rata-rata nilai hasil tes objektif terhadap 46 siswa sehingga diperoleh rata-ratanya 14.50 dengan standar deviasi 2,54. Setelah diketahui rata-rata dan standar deviasi, selanjutnya dilakukan pengelompokan dengan mengacu pada Tabel 1.

Berdasarkan kriteria pada Tabel 1, nilai rata-rata sebesar 14,50 dengan standar deviasi 2,54, maka kemampuan spasial dapat dikategorikan tinggi jika mencapai angka diatas atau sama dengan 17,04, kategori sedang jika berada pada interval 1,96 dan 17,04, dan kategori rendah jika dibawah 1,96. Dengan demikian, dari 46 siswa terdapat 6 siswa yang memiliki kemampuan spasial tinggi atau 13,04\%, 34 siswa yang memiliki kemampuan spasial sedang atau 73,92\% dan 6 siswa yang memiliki kemampuan spasial rendah atau $13,04 \%$.

Hasil kemampuan koneksi matematis untuk siswa yang memiliki kemampuan spasial tinggi mencapai skor 197 dari total skor 198, artinya kemampuan koneksi matematis siswa mencapai 99,49\%. Dari hasil ini dapat diketahui bahwa kemampuan koneksi matematis siswa yang memiliki kemampuan spasial tinggi tergolong sangat baik. Selanjutnya untuk kemampuan ini, siswa berkemampuan spasial tinggi sebanyak 6 siswa, $100 \%$ berada pada kategori sangat baik.

Hasil kemampuan koneksi matematis untuk siswa yang memiliki kemampuan spasial sedang mencapai skor 770 dari total skor 1.224, artinya kemampuan koneksi matematis siswa mencapai $62,91 \%$. Dari hasil ini dapat diketahui bahwa kemampuan koneksi matematis siswa yang memiliki kemampuan spasial sedang tergolong baik. Selanjutnya untuk kemampuan ini, dari 34 siswa berkemampuan spasial sedang, sebanyak 30 siswa atau $88,24 \%$ berada pada kategori baik dan sebanyak 4 siswa atau $11,76 \%$ berada pada kategori cukup.

Hasil kemampuan koneksi matematis untuk siswa yang memiliki kemampuan spasial rendah, mencapai skor 112 dari total skor 198, artinya kemampuan koneksi matematis siswa mencapai 56,56\%. Dari hasil ini dapat diketahui bahwa kemampuan koneksi matematis siswa yang memiliki kemampuan spasial rendah tergolong baik. Selanjutnya untuk kemampuan ini, dari 12 siswa berkemampuan spasial rendah sebanyak 3 siswa atau $50 \%$ berada pada kategori baik dan 3 orang siswa atau $50 \%$ lainnya berada pada kategori cukup.

Berdasarkan hasil tes yang diberikan nampak bahwa sebagian besar siswa memiliki kemampuan koneksi matematis yang baik. Hal ini terbukti dari hasil tes siswa yang telah dipaparkan sebelumnya bahwa banyak siswa yang paham dalam menyelesiakan soal kemampuan koneksi matematis ditinjau dari kemampuan spasial. Namun, untuk mengungkapkan kemampuan koneksi matematis ditinjau dari kemampuan spasial siswa yang sangat baik ini dalam mengerjakan soal-soal yang diberikan. Maka akan dilakukan adanya wawancara untuk dua soal yang sudah termuat ketiga indikator koneksi matematis tersebut.

Untuk menetukan responden yang akan diwawancarai, peneliti mengamati hasil tes siswa yang didasarkan pada kemampuan koneksi matematis ditinjau dari kemampuan 
spasial. Berdasarkan hasil tes siswa peserta tes dapat dikelompokkan sesuai pengelompokkan kemampuan spasial yaitu untuk siswa yang berkemampuan spasial tinggi, untuk siswa yang berkemampuan spasial sedang dan untuk siswa yang berkemampuan spasial rendah. Karena keterbatasan waktu dan kemampuan peneliti, sehingga untuk keperluan analisis data peneliti membatasi pada lingkup subjek penelitian yang menjadi responden untuk diwawancarai adalah berjumlah 3 orang. Hal ini disebabkan antara lain kegiatan wawancara guna mengungkapkan kemampuan koneksi matematis siswa yang berkemampuan spasial tinggi, yang berkemampuan spasial sedang dan yang berkemampuan spasial rendah. Sehingga peneliti memilih 3 subjek yang merupakan perwakilan dari tiga kategori yakni yang berkemampuan spasial tinggi, yang berkemampuan spasial sedang dan yang berkemampuan spasial rendah.

Pada siswa yang memiliki kemampuan spasial tinggi Berdasarkan hasil tes dapat diketahui bahwa responden mampu mengenal dan menggunakan hubungan antara ideide matematika, memahami bagaimana ide- ide matematika berhubungan dan saling berkaitan sehingga merupakan satu sistem yang utuh dan menerapkan matematika pada kehidupan sehari-hari dan dalam menjawab soal cenderung menghubungkan konsep-konsep matematik dengan konsep yang telah dikenal sebelumnya atau konsep yang sudah dipelajari terlihat dari rumus- rumus yang digunakan dalam penyelesaian soal yang ditempuh oleh reponden dimana responden dapat memahami konsep dasar dari soal tersebut. Berdasarkan wawancara responden sudah mampu menjelaskan dan menyebutkan konsep-konsep yang digunakan tersebut, dan menggunakan rumus yang tepat. Dalam hal ini menggunakan konsep yaitu rumus dalam penyelesaian soal yang didalamnya terdapat materi yang berhubungan dan responden juga mampu dalam menghubungkan konsep yang telah dikenal sebelumnya atau yang sudah dipelajarinya sehingga memproleh hasil yang tepat.

Pada siswa yang memiliki kemampuan spasial sedang berdasarkan hasil tes dapat diketahui bahwa responden mampu mengenal dan menggunakan hubungan antara ideide matematika, memahami bagaimana ide- ide matematika berhubungan dan saling berkaitan sehingga merupakan satu sistem yang utuh dan menerapkan matematika pada kehidupan sehari-hari dengan benar, tetapi tidak lengkap dimana responden mampu memberikan jawaban yang benar dapat menyimpulkan jawaban yang benar dari soal yang dikerjakan. Dalam hal ini, reponden mampu mengaitkan suatu konsep matematika berdasarkan soal yang dikerjakannya.

Berdasarkan hasil wawancara yang dilakukan, responden memberikan penjelasannya berdasarkan apa yang tertulis yakni menjelaskan strategi penyelesaian yang tepat. Pada siswa yang memiliki kemampuan spasial rendah berdasarkan hasil tes dapat diketahui bahwa responden tersebut sudah mampu mengenal dan menggunakan hubungan antara ide-ide matematika, memahami bagaimana ide-ide matematika berhubungan dan saling berkaitan sehingga merupakan satu sistem yang utuh dan menerapkan matematika pada kehidupan sehari-hari namun hanya sebagian yang benar dan hanya untuk beberapa nomor soal. Hal ini terlihat dari lembar kerja siswa, di mana siswa tidak menjawab semua soal. Berdasarkan wawancara, responden dapat mamahami permasalahan dalam soal yang berhubungan dengan ide matematika dalam kehidupan sehari-hari tetapi tidak mempu menuliskan dan merumuskan soal ke dalam bentuk matematika. 
S. Nuna, dkk | Identifikasi Kemampuan Koneksi Matematis Siswa Ditinjau dari Kemampuan ...

\subsection{Pembahasan}

Kemampuan koneksi matematis yang memiliki kemampuan spasial tinggi, berdasarkan hasil penelitian tergolong sangat baik yaitu mencapai 99,49\%. Dari hasil ini dapat diketahui bahwa kemampuan koneksi matematis siswa yang memiliki kemampuan spasial tinggi tergolong sangat baik. Siswa yang memiliki kemampuan sangat baik pada kemampuan koneksi matematis untuk siswa yang memiliki kemampuan spasial tinggi, artinya siswa tersebut sudah mampu mengenal dan menggunakan hubungan antara ide-ide matematika, memahami bagaimana ide-ide matematika berhubungan dan saling berkaitan sehingga merupakan satu sistem yang utuh dan menerapkan matematika pada kehidupan sehari- hari pada hampir semua soal.

Kemampuan koneksi matematis yang memiliki kemampuan spasial sedang, berdasarkan hasil penelitian tergolong baik, yaitu mencapai $62,91 \%$. Dari hasil ini dapat diketahui bahwa kemampuan koneksi matematis siswa yang memiliki kemampuan spasial sedang tergolong baik. Kemudian, kemampuan koneksi matematis siswa yang memiliki kemampuan spasial sedang ini dikategorikan sangat baik, baik, rendah dan cukup. Terdapat 30 siswa (88.24\%) berada pada kategori baik dan 4 orang siswa $(11.76 \%)$ berada pada kategori cukup dari 34 siswa berkemampuan spasial sedang. Siswa yang memiliki kategori baik pada kemampuan koneksi matematis untuk siswa yang memiliki kemampuan spasial sedang, artinya siswa tersebut sudah mampu mengenal dan menggunakan hubungan antara ide-ide matematika, memahami bagaimana ide-ide matematika berhubungan dan saling berkaitan sehingga merupakan satu sistem yang utuh dan menerapkan matematika pada kehidupan sehari- hari dengan benar, tetapi tidak lengkap. Kemudian untuk siswa kategori cukup, artinya siswa tersebut sudah mampu mengenal dan menggunakan hubungan antara ide- ide matematika, memahami bagaimana ide-ide matematika berhubungan dan saling berkaitan sehingga merupakan satu sistem yang utuh dan menerapkan matematika pada kehidupan sehari- hari namun hanya sebagian yang benar dan hanya untuk beberapa nomor soal

Kemampuan koneksi matematis yang memiliki kemampuan spasial rendah, berdasarkan hasil penelitian tergolong baik, yaitu mencapai $56.56 \%$. Dari hasil ini dapat diketahui bahwa kemampuan koneksi matematis siswa yang memiliki kemampuan spasial rendah tergolong baik. Kemudian, kemampuan koneksi matematis siswa yang memiliki kemampuan spasial rendah ini dikategorikan sangat baik, baik, rendah dan cukup. Terdapat 3 siswa (50\%) berada pada kategori baik dan 3 orang siswa (50\%) berada pada kategori cukup dari 6 siswa berkemampuan spasial rendah. Siswa yang memiliki kategori baik pada kemampuan koneksi matematis untuk siswa yang memiliki kemampuan spasial rendah, artinya siswa tersebut sudah mampu mengenal dan menggunakan hubungan antara ide-ide matematika, memahami bagaimana ide-ide matematika berhubungan dan saling berkaitan sehingga merupakan satu sistem yang utuh dan menerapkan matematika pada kehidupan sehari- hari dengan benar, tetapi tidak lengkap. Kemudian untuk siswa kategori cukup, artinya siswa tersebut sudah mampu mengenal dan menggunakan hubungan antara ide- ide matematika, memahami bagaimana ide-ide matematika berhubungan dan saling berkaitan sehingga merupakan satu sistem yang utuh dan menerapkan matematika pada kehidupan sehari-hari namun hanya sebagian yang benar dan hanya untuk beberapa nomor soal.

Dengan demikian dapat diketahui secara jelas bahwa kemampuan koneksi siswa tergolong sangat baik, dimana siswa belum mampu menyelesaikan soal dengan baik dan benar. Adapun faktor-faktor yang menyebabkan siswa tidak mampu 
menyelesaikan soal dengan baik dikarenakan siswa kurang memahami maksud dari pertanyaan yang ada dalam soal dan lupa materi-materi sebelumnya yang saling berkaitan sehingga menyebabkan siswa kurang benar dalam menyelesaikan permasalahan serta siswa sulit dalam membaca gambar. Hal ini berakibat pada kesalahan siswa dalam menentukan rumus. Oleh karena itu, untuk mengembangkan dan meningkatkan kemampuan koneksi matematis siswa pada materi limas dan prisma diperlukan latihan secara terus menerus oleh siswa itu sendiri dalam menyelesaikan masalah-masalah yang saling berkaitan dengan materi tersebut. Hal ini tentunya dibutuhkan motivasi dari siswa itu sendiri agar dapat mengembangkan konsep yang dimiliki melalui latihan soal yang bersifan kontinu. Selain melakukan latihan terus menerus siswa juga perlu mengembangkan kemampuan berpikirnya dengan terus memperbanyak informasi di luar jam pembelajaran karena pengetahuan siswa tidak hanya terbatas pada saat pembelajaran berlangsung dalam menerima materi, namun juga harus mengembangkan konsep-konsep yang telah di kenal sebelumnya atau yang telah dipelajari dalam kehidupan sehari

\section{Kesimpulan}

Kemampuan koneksi matematis siswa SMP Negeri 1 Telaga pada materi prisma dan limas ditinjau dari kemampuan spasial tinggi berada pada kategori sangat baik, sementara dari kemampuan spasial sedang dan rendah berada pada ketogori baik.

\section{Referensi}

[1] I. W. Anita, “Pengaruh Kecemasan Matematika (Mathematics Anxiety) terhadap Kemampuan Koneksi Matematis Siswa SMP," Infin. J., vol. 3, no. 1, pp. 125-132, 2014.

[2] S. Widyawati, "Pengaruh Kemampuan Koneksi Matematis Siswa terhadap Prestasi Belajar Matematika Ditinjau dari Gaya Belajar pada Materi Bangun Ruang Sisi Datar Siswa Kelas IX SMP di Kota Metro," J. Iqra' Kaji. Ilmu Pendidik., vol. 1, no. 1, pp. 47-68, 2016.

[3] I. F. Ulya, R. Irawati, and M. Maulana, "Peningkatan Kemampuan Koneksi Matematis dan Motivasi Belajar Siswa Menggunakan Pendekatan Kontekstual," J. Pena Ilm., vol. 1, no. 1, pp. 121-130, 2016.

[4] S. Isnaeni, A. Ansori, P. Akbar, and M. Bernard, "Analisis Kemampuan Koneksi Matematis Siswa SMP pada Materi Persamaan dan Pertidaksamaan Linear Satu Variabel," J. Educ., vol. 1, no. 2, pp. 309-316, 2019.

[5] N. D. Siregar and E. Surya, "Analysis of Students'Junior High School Mathematical Connection Ability," Int. J. Sci. Basic Appl. Res., vol. 33, no. 2, pp. 309-320, 2017.

[6] A. K. Kenedi, Y. Helsa, Y. Ariani, M. Zainil, and S. Hendri, "Mathematical Connection of Elementary School Students to Solve Mathematical Problems," J. Math. Educ., vol. 10, no. 1, pp. 69-80, 2019.

[7] H. N. Fajri, R. Johar, and M. Ikhsan, "Peningkatan Kemampuan Spasial dan SelfEfficacy Siswa Melalui Model Discovery Learning Berbasis Multimedia," Beta J. Tadris Mat., vol. 9, no. 2, pp. 180-196, 2017.

[8] B. Yilmaz and H. B. Y\ilmaz, “On the development and measurement of spatial 
S. Nuna, dkk | Identifikasi Kemampuan Koneksi Matematis Siswa Ditinjau dari Kemampuan ...

ability," Int. Electron. J. Elem. Educ., vol. 1, no. 2, pp. 83-96, 2017.

[9] A. P. Kusuma, "Implementasi Model Pembelajaran Student Teams Achievement Division dan Team Assisted Individualization ditinjau dari Kemampuan Spasial Siswa," Al-Jabar J. Pendidik. Mat., vol. 8, no. 2, pp. 135-144, Dec. 2017.

[10] D. Reilly, D. L. Neumann, and G. Andrews, "Gender Differences in Spatial Ability: Implications for STEM Education and Approaches to Reducing the Gender Gap for Parents and Educators," in Visual-spatial Ability in STEM Education, Cham: Springer International Publishing, 2017, pp. 195-224.

[11] F. Xie, L. Zhang, X. Chen, and Z. Xin, "Is Spatial Ability Related to Mathematical Ability: a Meta-analysis," Educ. Psychol. Rev., vol.32, no. 1, pp. 113-155, Mar. 2020.

[12] K. A. Gilligan, E. Flouri, and E. K. Farran, “The contribution of spatial ability to mathematics achievement in middle childhood," J. Exp. Child Psychol., vol. 163, pp. 107-125, Nov. 2017.

[13] M. Unlu and T. Horzum, "Mathematics Teacher Candidates' Definitions of Prism and Pyramid," Int. J. Res. Educ. Sci., vol. 4, no. 2, pp. 670-685, 2018.

[14] S. Khadijah, S. Ismail, and R. Resmawan, "Pengembangan Bahan Ajar Berbasis Penalaran pada Materi Sudut Pusat dan Sudut Keliling Lingkaran," Al-Khwarizmi J. Pendidik. Mat. dan Ilmu Pengetah. Alam, vol. 8, no. 1, pp. 1-12, Apr. 2020.

[15] S. D. Tamu, E. Hulukati, and I. Djakaria, "Pengembangan Modul dan Video Pembelajaran Matematika Persiapan Ujian Nasional pada Materi Dimensi Tiga," Jambura J. Math. Educ., vol. 1, no. 1, pp. 21-31, Mar. 2020.

[16] D. Wungguli and L. Yahya, "Pengaruh Penggunaan Media Berbasis Information and Communication Technology (ICT) terhadap Hasil Belajar Siswa pada Materi Dimensi Tiga," Jambura J. Math. Educ., vol. 1, no. 1, pp. 41-47, Mar. 2020. 